\title{
Study on Innovation Path of College Student Management from the Perspective of "Internet Plus"
}

\author{
Wuhua Zhang \\ Guangzhou Huashang Vocational College (China Guangzhou511300)
}

Keywords: "Internet plus"; High efficiency; Student management; Innovation

\begin{abstract}
The "Internet plus" is the combination of the Internet and the society of traditional industries, which broke the traditional modes of thought and behavior, and promoted the great social changes. This paper discusses the opportunities and challenges of the current "Internet plus" bringing to the management of college students, puts forward the "Internet plus" from the perspective of college students' innovation management path, hoping to make a contribution to enhance the work efficiency of the management of college students.

Since the Internet has entered China, it has penetrated into all aspects of Chinese social life, and is playing an increasingly fundamental role in all walks of life. The "Internet plus" thought that in the ideological management work of colleges and universities established the student-centered management thought and it can face the challenges and opportunities brought by "Internet plus" and enhance the management level. At present, there are still a lot of college management work can be improved, how to combine "Internet plus" with the college management is an important problem in student management in colleges must be thinking.
\end{abstract}

\section{Part One The Opportunities and Challenges Brought by "Internet plus" on the Management of College Students}

\section{The Opportunities Brought by "Internet plus" on the Management of College Students}

Firstly, the "Internet plus" can enhance the timeliness of information and make manager get information with the fastest speed and highest efficiency. The "Internet plus"breaks the information acquisition, and with the Internet tools especially some instant messaging software, the managers can make communication between students which becomes very convenient and fast. Secondly, "Internet plus" can enhance the affinity of college management work. Through the Internet, we can enhance communication between teachers and students, enhance interaction between teachers and students, establish a more equal, open and inclusive communication mode between teachers and students, and carry out student management in a more loving way, so as to reduce the difficulty of student work. Finally, it enriches the material for the management of the students. Teachers can collect students' favorite materials from the Internet, understand their ideological trends and hot topics, and formulate specific management methods according to specific problems, so as to improve their working efficiency.

\section{The Challenges Brought by "Internet plus" on the Management of College Students}

Firstly, the openness and diversification of the Internet have a impact on students' ideas. The Internet is an open system, and cultural diversity, information sharing and rich content are the fundamental attributes of the Internet. College students are at a critical stage of three viewpoints formation, lack of social experience, while have a lot of extreme, and the wrong thinking is easy to affect students' thought. At the same time, because Internet can greatly expand students' horizons, students' access to information has been improved qualitatively, which has increased the difficulty of teachers' mastery on students' ideological trend, and has greatly improved the difficulty of students management work. Secondly, many of the student management workers' original work methods have been unable to adapt to the current Internet age. In the new era, college students are strong in initiative and personality, and have strong self consciousness. Traditional management system and working way which are suppressed, disciplined, strict and single are very easy for students to get bored. There is a great gap between teachers and students. 


\section{Part Two Innovation Path of College Student Management from the Perspective of Internet Plus}

Student management is the foundation and core of daily management in colleges, and the effect of this work will inevitably affect the development of daily teaching and research in universities, and ultimately affect the reputation and strength of schools. The management of college students is a big workload which is tedious and complicated, but in the "Internet plus" era, modern information technology applied in the management of college students makes students management work become simple and efficient. In order to further enhance the management level of college students which are more closely connected with the students, and can build harmonious campus atmosphere, which means the student management staff must use Internet technology to overcome the traditional experience, constantly around the students' daily management and students' ideological innovation in management idea and mode to explore a new path of the management of college students from the perspective of Internet plus on university management work smoothly with laying a solid foundation. The following will discuss innovation path of college student management from the perspective of Internet plus:

\section{Innovation of the Concept of Student Management}

Innovation of the concept of student management is to open up the basis and premise of the path of innovation of the management of college students from the perspective of "Internet plus". Under the background of "Internet plus", the university managers should be aware of that students' concept has undergone major changes, and innovation of student management concept with the use of more acceptable, more popular management method for students can reduce the friction between the students and the management work more smoothly to carry out. With "Internet plus", student management workers should take the student as the management idea, in the process of student management, starting from the students thought considering the problem to find a solution to the problem which respects students' personality and innovative development and adjusts the working methods according to the features of the development of students, and to maximize students enthusiasm and promote college students' all-round development and constantly improve the core competence.

\section{Innovation of Student Management Work Model}

Innovation of student management work model opens up what is the main content of the innovation path of the management of college students from the perspective of "Internet plus". The traditional student management work has too many levels with low management efficiency and very slow information transmission efficiency. This rigid management mode can not adapt to the new changes of current student management work, and will also greatly restrict the improvement of student management. The application of Internet technology in the management of students makes the mode of student management innovation constantly. Under the "Internet plus" background, the university management chain continues to decrease, the structure of the organization currently becomes simplified, rigid, single control management mode, and the school students will be replaced by two-way control mode, and the new management model will be the platform, flat organization, starting from the specific needs and innovation of students in the daily life management and management ideas to discuss the specific path of this two-way management model innovation:

\section{The Foundation of Management Pattern Implementation}

Firstly, the management platform should be made. In the age of Internet, the biggest convenience and motivation is the platform. A management organization is changing towards the platform direction. It is the general trend of the whole world. This principle is also interlinked with the management of university students. This platform is based on the Internet where it can achieve the purpose of timely and rapid information feedback, resource sharing and timely communication. The college student management work platform is the purpose of a variety of Internet media, especially various kinds of instant communication tools, the integration of students, teachers, colleges and even the social forces and other various resources, schools and students, students and communication between people and other carrier to provide convenient, on the other hand, students 
can quickly grasp all kinds of information and get all kinds of resources and information for their own development and training needs, and timely feedback to upload platform. At the same time, through this platform, managers can grasp students' dynamics in time, improve their satisfaction with school management, and constantly improve their work according to their feedback, so as to improve their management level.

Secondly, the management organization is flat. In the past, the establishment of complex management institutions in colleges is too long for management chain and too complicated for management. Such an organization structure inevitably focuses on management rather than students, which is extremely unfavorable for student management. Under the "Internet plus" background, the students are the basis for the management of college students, and efficiency is the main body of student management, management mechanism requires the construction must be flat and close contact with the students to meet the students' various needs. Through Internet technology and ideas, colleges can revoke, merge and reconstruct the existing management departments to achieve seamless connection between institutions and students, and ensure the management of college students in a more efficient and concise way.

\section{Practice of Management Model}

Based on the characteristics of effective management, organizational platform and flattening, college student management workers can make full use of Internet tools to innovate the management mode of college students. Daily management of students and students' ideological management is the core and main content of the management of college students, following on from the two aspects to discuss how to carry out the innovation under the management of College students from the perspective of "Internet plus".

The first is the daily management of the students. This work is the basic content of the management of students in colleges. The student management workers should choose the most efficient and convenient ways and tools according to the specific work requirements, and carry out the daily management. Colleges should set up a student management client to collect, sort out and maintain information generated by students, and publish information related to students' interests. Student management workers, especially the Youth League Committee should transmit information to students through establishing WeChat group and QQ group, so that information can be transmitted to students quickly. At the same time, using these reproduced groups to carry out various kinds of study and discussion and work to make people brainstorm and learn from each other.

The second is the ideological management of the students. The ideological management of students is the most important thing in the management of students. On the one hand, student management workers should grasp the hot topics that most students are concerned about, on the one hand, grasping the students' thoughts and comments, so as to grasp their ideological trend. At the same time, we should give full play to the positive factors of the Internet, and quickly solve the problems of students' ideological problems, emotional problems, psychological problems, interpersonal communication and career planning. In view of the above questions, student workers can carry through the column, WeChat public and so on, timely communication with students can improve management efficiency, while the students in different grades, different students may have different problems, such as low grade extended learning and vision problems, work planning problem of high grade, according to the these problems, student management workers should do a good job planning, while strengthening the students between the transmission of information and communication and sharing of learning resources which helps to form a good style of study.

In summary, the innovation of college students management from the perspective of "Internet plus" is to make the student management work with the Internet thinking and technology, which will work electronic standardized procedures at the same time, and the student flat management structure and platform, student-centered can better serve the students. The management of students in colleges should make full use of the Internet, improve the management level of students' work, and make due efforts for the reputation of the school and the satisfaction of the students. 


\section{Reference}

[1] Zhenwei Li.Exploring the path of innovating the management mode of college students from the perspective of human based vision[J].Legality Vision,2016(02):289-290.

[2] Yonghui Luo.The innovation path of the management of college counselors in private colleges during the transition period[J].Quality Management in Fujian,2016(04):44.

[3] Yong Yan.Research on the innovation path of college student management mechanism-Taking Civil Aviation Flight University as an example[J].Theory of Learning,2016(05):202-204. 